\title{
CHANGES IN BLOOD HISTAMINE AND BRADYKININOGEN LEVELS DURING DIFFERENT PERIODS OF THE OESTROUS CYCLE IN GOATS
}

\author{
S. P. PRASAD, V. RAVIPRAKASH, M. SABIR AND \\ N. K. BHATTACHARYYA \\ Division of Physiology and Pharmacology, \\ Indian Veterinary Research Institute, Izatnagar, India
}

(Received 24th April 1974)

\begin{abstract}
Summary. Blood histamine and plasma bradykininogen levels were estimated in eighteen normally cyclic goats at different periods of the oestrous cycle. The histamine level increased significantly $(P<0.05)$ on Day 18 of the oestrous cycle. The bradykininogen level decreased significantly $(P<0.05)$ towards the end of oestrus.
\end{abstract}

\section{INTRODUCTION}

Histamine and the kinin-kininase system are reported to play a rôle in the mediation of the actions of reproductive hormones. The intraluminal application of histamine produces hyperaemia, vasodilatation, and oedema in the uterus and antihistamines, like diphenhydramine (Benadryl hydrochloride) and chlorpheniramine (Chlor-Trimenton maleate), block the oestrogeninduced changes (Spaziani \& Szego, 1959). Parenteral administration of oestrogen lowers the histamine content of the uterine tissues (Spaziani \& Szego, 1958), and the uterine histamine content in rats is significantly reduced during oestrus (Spaziani \& Szego, 1958; Kapila, 1967). These findings suggest that the action of oestrogen is possibly mediated through the local release of endogenous histamine.

Exogenous oestrogen increases the blood kininogen levels and decreases the kininase activity in rats (McCormick \& Senior, 1971, 1972).

The present investigation deals with the changes in the blood histamine and plasma bradykininogen levels during different periods of the oestrous cycle in goats.

\section{MATERIALS AND METHODS}

Eighteen healthy adult female goats of the Barbari breed, weighing 16 to $18 \mathrm{~kg}$ and 12 to 15 months old, were used in this study.

Vasectomized goats were paraded in the flock at 3-hr intervals every $24 \mathrm{hr}$ to detect the onset of oestrus.

Jugular blood samples were collected from individual goats (a) at the beginning of oestrus ( 0 to $6 \mathrm{hr}$ ), (b) near the end of oestrus (24 to $30 \mathrm{hr}$ ), 
(c) around metoestrus (48 to $54 \mathrm{hr}$ ), (d) during dioestrus (Days 6 and 12), and

(e) around pro-oestrus (Day 18).

Blood histamine was extracted by the method described by Parratt \& West (1957). The plasma bradykininogen level was determined by the method of Diniz \& Carvalho (1963). Processed samples were air-dried at room temperature $\left(32\right.$ to $\left.35^{\circ} \mathrm{G}\right)$ with an electric fan. The histamine and bradykininogen were assayed on the isolated guinea-pig ileum suspended in atropinized Tyrode solution $\left(37^{\circ} \mathrm{C}\right)$, using histamine acid phosphate (B.D.H.) and bradykinin (BRS; Sandoz) as standards.

Histamine values were expressed in terms of its base. The statistical analysis was carried out according to the methods of Snedecor \& Cochran (1968).

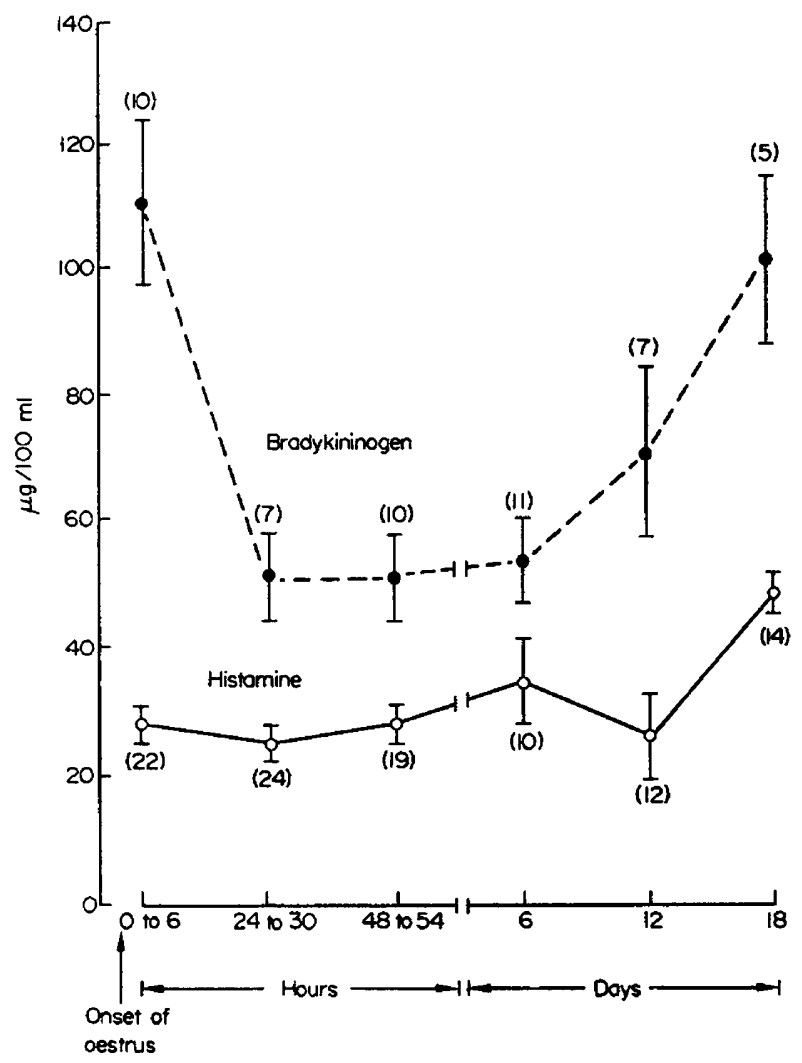

TExT-FIG. 1. Changes in blood histamine ( $O$ ) and plasma bradykininogen ( $\bullet$ ) levels at different stages of the oestrous cycle in goats. Vertical lines indicate standard errors. Numbers in parentheses indicate the number of observations.

\section{RESULTS}

The blood histamine level of the goats significantly increased $(P<0.05)$ from $23.9 \pm 5 \cdot 8 \mu \mathrm{g} / 100 \mathrm{ml}$ on Day 12 to $46 \cdot 6 \pm 7.69 \mu \mathrm{g} / 100 \mathrm{ml}$ on Day 18 of the oestrous cycle. With the onset of oestrus, the histamine level fell to a resting value. The plasma bradykininogen level gradually increased from Day 6 of the oestrous cycle, reached the highest value at the beginning of oestrus and fell from 


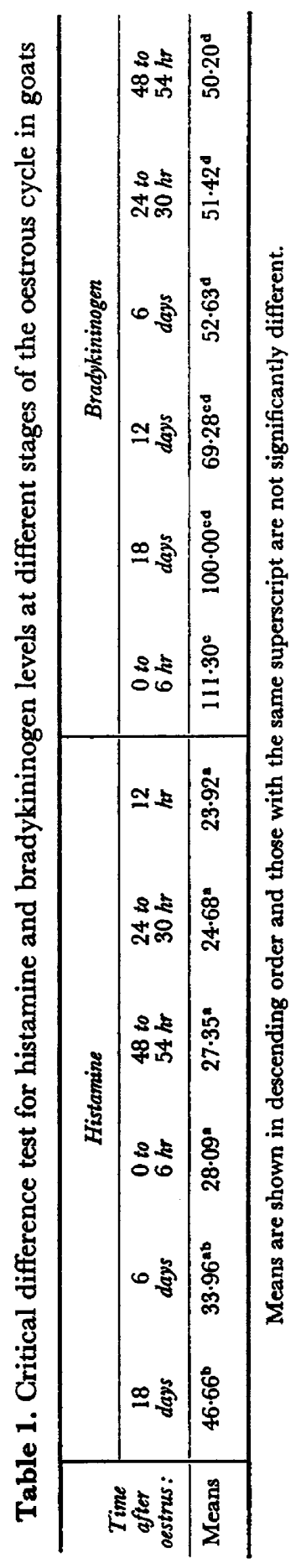


$111 \cdot 3 \pm 23 \cdot 2 \mu \mathrm{g} / 100 \mathrm{ml}$ at 0 to $6 \mathrm{hr}$ to $51 \cdot 4 \pm 7 \cdot 4 \mu \mathrm{g} / 100 \mathrm{ml}$ at 24 to $30 \mathrm{hr}(P<0 \cdot 05)$ after the onset of oestrus (Table 1 and Text-fig. 1).

\section{DISCUSSION}

Spaziani \& Szego (1958) and Kapila (1967) observed a significant decrease in the histamine content of rat uterine tissue during oestrus. In the present study, the significant increase of blood histamine preceding pro-oestrus and the subsequent fall at the onset of oestrus (Text-fig. 1) suggest the possible involvement of histamine in the concurrent changes in the uterine tract under the influence of oestrogens.

Increase in blood kininogen level has also been observed after the exogenous administration of oestrogen (McCormick \& Senior, 1971). The fall in the bradykininogen level in goats has been shown to coincide with the increase in the percentage of ovulation (Prasad, 1974). Levels of 35 and $77 \%$ ovulation occurred 24 and $32 \mathrm{hr}$, respectively, after the onset of oestrus. This finding needs further investigation.

\section{ACKNOWLEDGMENTS}

Professor N. K. Bhide of the All-India Institute of Medical Sciences, New Delhi, kindly provided the bradykinin. The fellowship granted to S.P.P. by the Council of Scientific and Industrial Research, New Delhi, is gratefully acknowledged. Thanks are due to the Director, Indian Veterinary Research Institute, Izatnagar, for providing the necessary facilities.

\section{REFERENCES}

Diniz, C. R. \& Carvalho, I. F. (1963) A micromethod for determination of bradykininogen under several conditions. Ann. N.Y. Acad. Sci. 104, 77-89.

KAPILA, K. (1967) Histamine content of albino rat uterus during estrous cycle and early pregnancy. Ind. F. Physiol. Pharmac. 11, 127-128.

McCormick, J. T. \& SENIOR, J. (1971) Effect of sex hormones on the concentrations of plasma kininogen in the female rat. Br. F. Pharmac. Chemother. 43, 421p-422P.

McCormick, J. T. \& Senior, J. (1972) The effect of the oestrous cycle, pregnancy and reproductive hormones on the kininase activity of rat blood. F. Reprod. Fert. 30, 381-387.

Parratr, J. R. \& West, G. B. (1957) 5-Hydroxytryptamine and tissue mast cells. F. Physiol., Lond. 137, $169-178$.

PRASAD, S. P. (1974) Studies on some aspects of reproduction in Barbari nannies. Ph.D. thesis, Agra University Agra.

Snedecor, G. W. \& Cochran, W. G. (1968) Statistical Methods. Indian Edition, Oxford and IBH Publishing Company, Calcutta.

Spaziani, E. \& Szego, C. M. (1958) The influence of estradiol and cortisol on uterine histamine of the ovariectomized rat. Endocrinology, 63, 669-678.

Spaziani, E. \& Szego, G. M. (1959) Further evidence for mediation by histamine of estrogenic stimulation of the rat uterus. Endocrinology, 64, 713-723. 